\title{
Tourism development and Human Resources challenges (Gjirokastra Region)
}

\author{
Daniela Qiqi ${ }^{\mathrm{a}}$ - PhD (c), Lindita Rova ${ }^{\mathrm{b}}$ - PhD (c)
}

\begin{abstract}
The economic development of many countries in general, depends on a large extent on the development of the tertiary sector and tourism is one of the most important components of this sector. Tourism significantly affects GDP growth, export growth, environmental protection and also employs many people. As a result, many developing countries promote tourism as a tool for economic and social development. In our country tourism development tends to be one of the main ways to alleviate the problem of high unemployment.

Human resources play a vital role as an important element in the organization's performance for achieving its economic objectives. This role is increased even more in the case of organizations that provide services. This means that it is necessary to ensure high standards of quality and efficiency of HR. Intended objectives can only be achieved by defining the specific needs of human resources development in various segments of the sector.
\end{abstract}

Keyword: Human Resources, Tourism, Training, Education system, Gjirokastra

\section{The Importance of Tourism Development}

Tourism is an important economic activity worldwide. There is a direct and an indirect impact of this sector in the economic development and in the number of employees. This paper is mainly based on the national and international institution's data but we must mention that the revenues of this sector are higher than statistic data shows. There are practical difficulties in the right collection of this sector's data because of the diverse structure of its services and it's all inclusive nature. However, based on the report made by WTTC (World Travel \& Tourism Council), we can mention that in Albania the total contribution of Tourism \& Travel in GDP for 2013 was 68.1 bn ALL or 4,8\% of GDP and it is predicted to grow by $5.5 \%$ up to 71.9 bn ALL in 2014. The forecast for 2024 shows a growth up to 123.6 bn ALL or $6.1 \%$ of GDP. ${ }^{1}$

An element with great importance in the sector of tourism is the number of its employees. Referring to the same report made by WTTC (World Travel \& Tourism

${ }^{1}$ WTTC, Travel \& Tourism Economic Impact, 2014, Albania, pg 3

${ }^{a}$ Lecturer, Faculty of Education and Social Sciences, Economic Department

Gjirokastra University, Albania.

bDirector of Regional Educational Directorate, Gjirokaster, Albania

Assistant Lecturer at Gjirokastra University. 
Council), Travel \& Tourism created 41.000 jobs directly in 2013 or $4.3 \%$ of total employment and it is predicted to grow by $5.2 \%$ in 2014 up to 43.500 jobs, representing $4.4 \%$ of the total employment. The forecast shows that Travel \& Tourism will have a growth of $3.5 \%$ in the next decade, accounting 61.000 jobs directly by 20242 .

Furthermore, Albanian Government considers tourism a sector that will have a large impact on the expected quantitative and qualitative development of Albanian economy in the next 4 years. The Ministry of Urban Development and Tourism seems to be seriously engaged in the launching of several documents regarding the tourism development such as the new law of tourism; the National Strategy of Tourism for the period 2014-2020 aiming the incentive and the development of sustainable tourism; the licensing, the standardization, the certification of tourism services, to develop informative campaigns and promotions for the new face of Albanian tourism which is intended to be achieved through protection, development, promotion of touristic resources; Albanian culture and heritage etc. ${ }^{3}$

As a result of the specific nature of this sector the employees in it are mainly females and youth. Based on statistical data, the unemployment rate in Albania for 2013 was 15.6\%, $13.2 \%$ for the unemployed females. Whilst the unemployment rate for the youth between 15-24 years old was 30,2\%, which compared with the data in 2012 showed a growth of 2,3\%.4Data shows that youth and females are really limited in the labor market. These groups face a lot of challenges regarding the labor market indexes. This is the reason why Albania considers the tourism development as a chance to decrease the unemployment rate as well as to better off the living standard of the country. The Albanian Investment Development Agency AIDA ${ }^{5}$ ranks tourism in the third place, with energy and industry in the first two places, as a sector with high investment potentials.

Even though all these actions are good for the tourism development, drafting qualitative policies is not enough. Are there human resources competent enough to make these policies give the expected results? Human resources and their job competence are vitally important elements in the tourism sector because the kind of the product that this sector provides is mainly services. As a result of this fact it largely depends on the quantity and the quality of the included human resources.

Is it clear for the local and central government authorities the importance of the human resource's development? Are the attempts made in the right direction for the preparation of tourism specialist and a sustainable tourism development?

\section{The Human Resources Role And The Conditions Of Their Training In Albania}

The connection between education and economic development has been in the center of the development studies, focused on long term growth, for many years. Whilst in the theoretical models education is known as a key factor in the economic growth of a country, in the empirical models education has a small importance. The reason of this discrepancy is the fact that education for a long time was measured based on years

\footnotetext{
${ }^{2}$ Idem, pg 4

${ }^{3} \mathrm{http}: / /$ turizmi.gov.al/al/

${ }^{4}$ www.instat.gov.al/papunesianevite

${ }^{5}$ www.AIDA.gov.al
} 
school was frequented and not on the level of knowledge and skills obtained during school years, which according to a OSCE study, a student competence growth of 100 points (measuring unit) produces an increase of $2 \%$ of PBB per person. Thanks to this fact education is known as a key factor for development ${ }^{6}$.

In the academic literature human resource is considered to be an important indicator of individual and general productivity. ${ }^{7}$ Zeick (2002) mentioned that in German companies, the high number of employees that participated in training courses increased the annual production. Several studies, made in the developed countries, showed that any kind of education combined with training courses have a positive impact on the productivity growth, which on the other side helps in the economic development of a country (Lucas, 1988).

The sustainable development of the tourism sector is a challenge that all the factors involved in it face. Only competent human resources can help in the achievement of the determined economic standards and targets. Nowadays, we can't operate with the idea that economy should be in function of education, but with the idea that education should be adjusted to the economic and social development, because education is one of the most important factors in the sustainable development.

The preparation of Human Resources capable of being employed in the tourism sector requires an infrastructure made of educational and training institutions. Moreover it is necessary the drafting of programs that offer the chance to adjust the existing competent employees to the market requirements that change constantly. The training of human resources should be continuous because labor requirements change and as a result of this change, the human resources abilities should improve to keep the required standards of the service's quality. So, training is one of the most important aspects of the total human resources investment for a business. Developed countries spend considerable amounts of money for human resources training as well as for drafting development training programs. The constant development, the change of the market conditions, increased knowledge, changing the problems solving methods, increase the need of the businesses to recruit trained human resources, but also makes necessary the training of the existing human resources. As a result, it is impossible the implementation of the targets set without the provision of a continuous human resources training.

Albanian educational institutions of secondary and higher level should pay attention not only to the quantity of the human capital but to the quality also, because this is the only way the expected development in tourism and in the whole economy will be achieved. What's the actual situation of education, and especially of the vocational education, in Albania?

\subsection{Vocational Education in Albania}

To better understand the human resources impact on the economic development and the challenges that vocational education faces in Albania, a synthetic description of its actual structure will be represented based on a report made by ACCE for the secondary educational system in Albania. Nowadays the educational structure is (primary3+3)+(lower secondary 3)+(higher secondary 3).

\footnotetext{
${ }^{6}$ Education at a Glance 2013, OECD indicators, 25 june 2013
}

${ }^{7}$ Bassanini e Scarpetta, 2001; Fuente e Ciccone, 2003; Jones, 2005 e Bassanini, 2007 
Currently, 41 technical schools and 33 socio-cultural schools (5 of which are together with technical-professional schools) operate in the country level, distributed in 22 localities. Three of these professional schools operate in the rural zone with an agricultural direction. Schools are divided in 4 main areas: electro-mechanical, (19 schools), economic (9 schools), construction-joinery (4 schools); agriculture, woods/forests, veterinary medicine (9 schools). Pupils are prepared for 35 different specialties. ${ }^{8}$

Since $2009 / 10$, the primary vocational education is organized in 3 levels so that it can offer the students a general education as well as a vocational one (theoretical and practical), thus preparing them for work and for further education. The 2-years programs of the first level aim the training of the semi skilled workers. Successful students take a basic professional certificate that allows them to enter the labor market or to continue their studies in the next level. In the second level, the one-year programs prepare technicians with a professional training certificate. The completion of the technical programs in the third level, that takes one more year, gives them the chance to continue their studies in a higher level. In the end of the third level students take the state exams and the professional practice exam. This new system is a successful one because has grown the number of registrations in the vocational schools from $19 \%$ in 2009 to $51 \%$ in 2011 .

As shown from the above data, the vocational schools directions don't meet the labor market requirements or the economic branches classification of the country which is based on their development and on their number of employees. Generally, low level students choose vocational schools ${ }^{10}$. The proper structuring of education is not enough because restructuring the curricula and increasing the quality of the information given play also a vital role.

Referring the World Bank reports, for education the report of 2008 notes that "The theoretical overloading issue is more concerning than the curricula one". The report of 2009 notes, as well that educational program is overloaded with concepts and it has a theoretical nature. There's a lack of practice in the educational system. There's also a lack of the modern methods of learning in the context of promoting the critical thinking, the team work and the individual work. According to this report the normalization of the student's workload is a target that can be achieved by the elimination of the needless material as well as by the consolidation of the curricula reform, providing students with a sufficient time to stimulate the independent, critical and creative thinking, for nurturing the team work etc. ${ }^{11}$

Concluding, we can say that the educational system in Albania faces a lot of challenges. Besides those mentioned above we can add that the radical reform drafted by the Ministry of Education in Albania should be guided toward the labor market. To make it more clear we can mention the fact that based on the INSTAT data in Albania about $48 \%$ of the employees work in the Agricultural sector, but as mentioned above there are only 3 agricultural schools in the country. Moreover there is no vocational school that

${ }^{8}$ Albanian Coalition for Child Education (ACCE), Albania: The situation of educational system, march, 2013,pg 2

${ }^{9}$ The Ministry of Social Welfare and youth, Employment Strategy 2014-2020

${ }^{10}$ Idem

${ }^{11}$ World Bank Report, 2009 
can prepare skillful human resources for tourism, even though it is considered to be a strategic sector in the future.

\section{Gjirokastra, Tourism And Human Resources Challenges}

The region of Gjirokastra is one of the 12 regions in Albania, with a surface of $2.884 \mathrm{~km}^{2}$ and a population of 73556 residents ${ }^{12}$. The district of Gjirokastra lies in the southeast of Albania, it consists of 3 localities, Gjirokastra,Tepelena and Permeti. Its administrative center is the city of Gjirokastra. In the Development Strategy of Gjirokastra District 2005-2015, tourism is considered to be a development perspective and it will constitute the main source of revenues growth. This is a conclusion based on the great potentials for the tourism development in this zone. The great touristic potential is based mainly on the existence of the antic city of Gjirokastra, created in the XII century around a fortress on a hill.13 Moreover Gjirokastra owns characteristic houses, the Argjiro castle, the archaeological sites of Antigonea and Hadrianopolis, and more than 500 historic buildings that give Girokastra a stunning and unforgettable view. In 2005 Gjirokastra became part of the world heritage list of UNESCO for its unique characteristics and its architectural values. This fact increases the touristic values of the city. Other zones of the district also own cultural touristic resources and worth mentioning are: Religion Objects of Labova, Leuse, Melan, Cepo, Çatiste, Hormova etc. The sources of this region fulfill the requirements not only for the development of cultural tourism but for exploring tourism, river tourism, alpine tourism and eco-tourism. In this zone are found about 150 natural monuments, among them: Uji i Ftohtë in Tepelena, Viroi Lake in Gjirokastra, National Park of Hotova in Përmet etc. Nemëcka Mountain and Bënça Valley canyons, Progonat and Nivicë (Tepelena) caves, Vjosa Valley etc offer breathtaking views. In Bënjë of Përmeti are found the thermal waters known for their curative abilities. Culinary or otherwise Iso-Polifonia labe (a spiritual value certificated from UNESCO as an asset of World Cultural Heritage), are specific elements that attract domestic and foreign tourist to visit the district of Gjirokastra. The region of Gjirokastra has a great potential for the touristic development because it owns a rich touristic supply leaded by the historical-cultural tourism, followed by natural tourism, the archeological one and so on. As a conclusion we can say that Gjirokastra District has all the potentials, besides the sea, to treat tourism as a possibility of its economic growth.

According to statistics in 2012 the number of tourists was about 25000, and the last years this number has increased. Furthermore the number of the hospitality structures, mainly hotels and restaurants has grown. Currently the number of the hotels in the district is about 56, where 32 of them are in the city of Gjirokastra and the number of coffee-bars and restaurants is about 49. Many studies have concluded that the services quality that touristic structures offer, are closely related with the quality of human resources. Businesses operating in tourism have shown their concern because of the lack in the competent human resources for this sector. Moreover, graduates in this sector face challenges like employment seasonality, the switching between the educational system to the employment for the first time, the low wages etc. According to Labor Force Survey

12 www.istat.gov.al, 2014

13 J. Guillemin, Anthropological Realities: Readings in the Science of Culture, New Brunswick, N.J, Transaction Publishers, $1^{\circ}$ gennaio 1980, pg. 387. 
in 2011, youth are unemployed at least 4 years before getting their first job. Thus, the time spent waiting for a job means loss of productivity in the labor market. In 2012 , the employees of hospitality sector had the lowest income on average (23,090 ALL per month).Based on everything mentioned above and considering the report of the employment strategy, the essence of vocational education in Albania should switch from production to service professions(economy, management, hotel, tourism and Communication Innovation Technology)

In terms of educational system, Gjirokastra district has 31 elementary schools which last 9-years, 9 united high schools, which means that high school is united with the elementary school, 8 high schools of general profile and only 2 vocational schools, one industrial school (with 3 specialties: auto, hydro and electro) and one art school (with 4 specialties: canto, painting, sculpture, musical instruments). There is only one course included in elementary school curricula that helps students learn more about their native land and it is called "Know your Native Land". But, a considerable number of courses have different projects that help students know better the cultural and historic wealth of the zone. There is a lack of courses that include information about tourism and its economic and social impact or information about the historic, archeological, cultural and natural heritage of this zone. The existing vocational schools do not meet the requirement of the labor market in a region like Gjirokastra that aspires to develop tourism with European or Global standards. Based on the region strategy and on the labor market, we can say that changing the specialties of the existing vocational schools or even open new vocational schools like: wood and stone processing schools, maintenance or restoration of cultural monuments schools would have a positive impact on employment and on economic development. Moreover the orientation of the art school toward art \& design would help to develop the souvenirs market and to cultivate the traditional musical culture, since isopolifonia is a value protected by UNESCO. A really productive action would be the opening of a new tourism school, because with that the labor market would have competent human resources to fulfill the strategy of the region development.

Since the city of Giirokastra has a university, its residents majority, about $57 \%$, is under 35 years old ${ }^{14}$. The Tourism Department in the "E'qrem Cabej" University exists since 2005 and offers undergraduate and postgraduate courses. The results of a questionnaire, made for the needs of this paper to tourism students, showed that $85 \%$ of respondents think that tourism is a sector that should be developed in Gjirokastra but only $25 \%$ of them are willing to work and succeed in this sector, while $71 \%$ would like to be employed in the public sector, $15 \%$ in the private sector and 14\% to start their own business. Furthermore, the survey respondents consider necessary the switching from theoretical curricula to more practical ones, by strengthening the cooperation between the university and the private market.

The survey results lead us to the conclusion that tourism is considered to be an important sector for the future of this zone, but its human resources lack of professional competence in this sector makes them hesitant about their future in tourism. Even though university gives knowledge about the reasons why things happen and their impacts, vocational education teaches how to become competent for a specific sector. There's a lack of this vocational training in the educational system of Gjirokastra, leaving

${ }^{14}$ www.aida.gov.al 
the labor market without competent human resources for tourism. The only institution that offers some kind of professional courses for any resident of the city is the Professional Training Center (PTC), which operates under the dependence of the Ministry of Social Welfare and Youth. This center offers 41 training courses, some of them are connected to tourism, but the statistical data show that the participation in these courses is extremely low and even the courses that have a considerable number of participants have nothing to do with the sector of tourism. The Employment Strategy 2014-2020 notes: "Public PTC are not fulfilling their mission. It is offered a low quality training, they use old programs that most of the time are not based on the curricula, there is a lack of learning materials; a lack of funds for the drafting of new programs; their courses have a short duration and their instructors are of a low quality. There is no cooperation between PTC and the private sector, neither between PTC and professional schools, fact that creates a gap between the labor market requirements and the trained human resources. ". Based on these facts we conclude that despite their functioning problems, the training courses can not create competent human resources in tourism sector without a proper educational system that starts in the elementary levels and ends with the higher level. So, "Vocational Education in Tourism" is a stepping stone for the creation of a developed and contemporary industry in tourism. In the same time the finding of new instruments for the coordination of economic policies and labor ones, that can lead the university and the governmental bodies towards the promotion of education, to increase the quality of undergraduate and postgraduate education, play a vital role in the tourism development. Simultaneously, a cooperation between the private sector and universities operating in the same zone should be created so that the labor market requirements can be fulfilled and the graduates can immediately get employed.

\section{Conclusions}

- Different facts and factors prove that tourism development can cause economic development and that Girokastra region owns a great potential for this development, especially the cultural one.

- $\quad$ The quality of human resources that are occupied in the touristic sector play the most important role in the determination of this sector success.

- The touristic educational institutions have mainly theoretical courses, creating a lack of practical experience for their graduates, making them hesitate to work in the sector.

- There's a lack of competent professionals in the Albanian touristic sector.

- The educational and training institutions are not capable of creating professionals that meet the touristic sector requirements.

These are the reasons why we think that coordination of all interest groups operating in the touristic sector will help human resources occupied in this sector to excess all the challenges they face. Furthermore, the touristic sector can become the sector with the higher revenues of Gjirokastra region only by the coordination of all the local actors and economic policies as well as by adjusting the current educational infrastructure with the touristic labor market requirements. 


\section{Bibliography}

Albanian Coalition for Child Education (ACCE), Albania: The situation of educational system, march, 2013

Bassanini, A., Scarpettta, S.(2001) Does Human Capital Matter for Growth in OECD Countries? OECD economics department, working papers no. 282

Education at a Glance 2013, OECD indicators, 25 June 2013

Fuente, A., Ciccone, A. (2003), Human Capital in a Global and Knowledge-Based Economy, final report, Employment and Social affairs.

Guillemin, J. (1980 January) Anthropological Realities: Readings in the Science of Culture, New Brunswick, N.J, Transaction Publishers

Koçiu, L., Çelo.R., Muço, K. (2013 April) The Impact of Foreign Direct Investment on the Tourism Development in Gjirokastra, Institute of scientific research and development,Pg.67-74

Lucas, R. (1988), On the mechanics of economic development, Journal of Monetary Economics

World Bank Report, 2009

Zeick,T. (2002). Continuous Training and Firm Productivity in Germany, ZEE Discussion 